\title{
Trends in the distribution of added value of listed industrial companies - 1990 to 2002
}

\author{
N. van Aswegen \\ Graduate School of Business, University of Stellenbosch, \\ PO Box 610, Bellville 7535, Republic of South Africa \\ B.W. Steyn* \\ Department of Accountancy, University of Stellenbosch \\ Stellenbosch 7600, Republic of South Africa \\ bws1@sun.ac.za \\ W.D. Hamman \\ Graduate School of Business, University of Stellenbosch, \\ PO Box 610, Bellville 7535, Republic of South Africa
}

Received October 2004

\begin{abstract}
Value added is a measure of the increase in wealth of a company. The question posed in this paper, is whether there was a change over time; firstly in the percentage of added value by companies as a proportion of sales and secondly in the distribution of the added value between the different stakeholder groups.
\end{abstract}

The ratio VA/sales and the VA distribution ratios were calculated for three samples:

- A full sample from 1990 to 2002, consisting of all the listed South African companies preparing a value added statement;

- A constant sample of 36 companies that existed from 1990 to 2002; and

- $\quad$ A constant sample of 55 companies that existed from 1994 to 2002.

Although a slight downward trend was found in VA/sales from 1997/1998, there is not enough evidence to infer that there was a change over time in VA/sales as the differences in the central location for at least two years were not significant.

It was determined that there was only one distribution ratio in each constant sample with a significant difference in the central locations between at least two of the years. These ratios were retention/VA for the constant sample from 1990 to 2002 and depreciation/VA for the constant sample from 1994 to 2002.

The change over time in depreciation was probably caused by the change in accounting treatment for amortisation of intangible assets. Retention is a balancing figure - the leftovers after the other allocations have been done - it can therefore be expected that this ratio will be influenced by the changes in all the other allocations. The general prosperity of the company and the economy will also influence retention, as the total value added will change accordingly and that will determine what is being left for retention in the company. As the growth in the GDP increased during the period under review, it was no surprise to find an increase in the ratio retention/VA.

*To whom all correspondence should be addressed.

\section{Introduction}

Social corporate reporting is emerging as a means to communicate information to the stakeholders of a company in a much broader way than the financial statements that are required by Generally Accepted Accounting Practice. The income statement, cash flow statement and balance sheet report the financial results, the change in financial position and the financial position of a company to its users, with the shareholders as the most important group provided for. In order to fulfil the need for a financial statement that does not mainly focus on the shareholders, but addresses the interests of employees and government, the value added statement was developed.

Value added is a measure of the economic performance, or increase in wealth, of a company. It can be expected that each stakeholder group would demand their rightful portion (according to their own perceptions) of the value created by the company. The question posed in this paper, is whether there was a change over time; firstly in the percentage of added value by companies as a proportion of sales and 
secondly in the distribution of the added value between the different stakeholder groups.

\section{Literature review}

\section{Introduction}

Although the notion of value added can be traced back to the $18^{\text {th }}$ century, renewed interest in this as an economic concept occurred after the Second World War. In 1975, the Accounting Standards Steering Committee of the United Kingdom published The Corporate Report, which recommended the use of a value added statement. The publication of a value added statement is not mandatory in South Africa and no South African standard exists pertaining to the preparation of value added statements. The Corporate Report advised that a minimum of eight items be included in a statement in order to consider it a value added statement (VAS): sales (S), bought-in materials (B), depreciation (Dep), dividends (Div), interest (I), salaries and wages (W), taxation (T) and retained earnings (R). Added value is calculated by deducting bought-in materials and services from sales; where after the distribution of the added value to the various stakeholders is segregated. Therefore:

Value added $(\mathrm{VA})=\mathrm{S}-\mathrm{B}$, and

The distribution of VA $=$ Div $+\mathrm{I}+\mathrm{W}+\mathrm{T}+\mathrm{Dep}+\mathrm{R}$

\section{Usefulness of value added statement ratios}

Value added is a measure of the wealth created by the activities of a company. Value added based financial ratio analysis, although similar to traditional financial analysis, differs in the following respect, namely that the value added based ratios include value added in either the numerator or the denominator. Since value added represents the total economic return of the company, ratios thus calculated have greater informative value than those based on concepts that are more restricted like net profit (Riahi-Belkaoui, 1992:113).

Ratios generated from value added statements may thus be used successfully as diagnostic and predictive instruments (Morley, 1979:621). In addition, when employed in a sophisticated manner, these ratios may be used as benchmarks against which companies may judge their performance relative to other companies within their industry (Rutherford, 1981:33).

Value added ratio analysis has also been used to measure, amongst other things, the following:

- Managerial efficiency

- $\quad$ Productive efficiency

- Component contribution to total return

- Degree of vertical integration

- Immediate benefit to shareholders

- Company flexibility

- Research intensity of the company (Riahi-Belkaoui, 1992:113-116).

\section{Value added as a proportion of sales}

Value added as a proportion of sales has been used to measure the degree of vertical integration of a company (The Value Added Scoreboard, 2004: 28). A ratio of 1 (or $100 \%$ ) indicates that a company is fully vertically integrated. This could only be achieved if an organisation provided a service without making use of bought-in materials or services of any kind. The higher the ratio, the more vulnerable a company may be to changing market demands (Cox, 1979:75). A company with a ratio close to zero does not add much value since it mostly employs outside services (Haller \& Stolowy, 1995:9). The operations of such a company are highly dependent on its suppliers and are therefore heavily exposed to the possibility of disruptive action beyond its own control (Morley, 1979:622).

Value added as a proportion of sales also gives an indication of the productive, or economic, efficiency of a company (Riahi-Belkaoui, 1992:114). In other words, value added as a proportion of sales indicates the extent to which a company has managed to utilise its factors of production. It should however be noted that this ratio varies depending on the nature of the industry (Bryant, 1989:35).

In the United Kingdom the ratio VA/sales was found to have decreased significantly from the late 1960s to the late 1980s. By 1987, the average level of this ratio over all sectors was $30 \%$. It has been suggested that the observed decline in $\mathrm{VA} /$ sales may be attributed to technological advances that altered the manner in which business was conducted. It may also be because the outsourcing of business functions became far more popular. It is even speculated that the forces of global competition may have forced companies to scale down their operations considerably, thus causing the observed decrease in the overall ratio (Bryant, 1989:38).

\section{Distribution of value added components as a percentage of value added}

These ratios have also been referred to as the value added distribution ratios (Haller \& Stolowy, 1995:10). The ratios show the proportion of company value added which has been distributed to each of the stakeholders: employees (salaries and wages), debt holders (interest), shareholders (dividends) and government (taxation). In addition, it also illustrates the portion retained by the company (retained earnings) and that which was expended on depreciation.

The percentage value added applied for each of the abovementioned purposes may vary greatly between industry sectors, due to inherent differences in the nature of each industry (United Kingdom, 2004: 28).

The ratio salaries/VA provides an indication of the relative importance of labour as a factor of production in a company (Haller \& Stolowy, 1995:10).

\section{South African studies}

A study, which examined South African financial ratios, revealed that in aggregate this data, as is true elsewhere in the world, is usually not normally distributed. The finding of 
non-normality persisted even after outliers were removed from the data. It would therefore be imprudent to assume normality in any distribution of financial ratios (Jordaan, Smit \& Hamman, 1994:71).

Little empirical work has been done on ratio analysis of value added statements in South Africa. A study presented in 1999 examined certain value added statement ratios over the period 1991 to 1997 (Hamman \& Burger, 1999). The study described the characteristics of the ratios on an aggregate and on a per sector basis. It was found that value added as a percentage of sales did not alter significantly in aggregate over the period under review. A mean of 32,98\% and a median of $31,61 \%$ were observed for this ratio over the whole period studied. It was however established that this ratio differed between sectors (Hamman \& Burger, 1999: 263).

When the distribution-components of value added as a percentage of value added were examined, some ratios appeared to vary more than others do. Salaries/VA increased in 1991 and 1992 and then decreased. Dividends/VA and taxation/VA tended to decrease over time, while retention/VA increased steadily (Hamman \& Burger, 1999:264). The sample used, however, was not constant, that is, it did not consist of the same companies from year to year.

The purpose of this paper is firstly to provide descriptive statistics on added value by industrial listed companies in South Africa and secondly to determine whether there was a shift over time in VA as a percentage of sales as well as whether there was a significant change in the distribution of added value among the various stakeholders over time.

\section{Methodology}

The data used in this study was obtained from a database that contains information gathered from the value added statements of industrial companies listed on the JSE Securities Exchange as they appear in the annual reports of these companies. In addition, since no specific standards or guidelines govern the publication of the value added statement, the data obtained directly from company value added statements were standardised, according to the following definition of distribution of value added:

Distribution of value added = dividends (ordinary and preference) + depreciation + net interest paid + salaries and wages + taxation paid + retained income + minority interest.

The standardisation also involved comparison of the items in the value added statements with those values published in the corresponding income statements. If any discrepancies were identified, the figure published in the income statement was used, since the income statement is an audited document. The standardisation process makes it possible to utilise the value added statement components of different companies in an equivalent manner.

All industrial companies, which produced a value added statement from 1990 to 2002, were included to calculate the descriptive statistics. The companies that were newly listed and those that were delisted during the period under review were all included. The sample also incorporated companies which produced a cash value added statement, since the standardisation process applied allowed meaningful comparison of such statements with value added statements based on accrual information. The following number of companies that published a value added statement in each of the years under review was included in the full sample:

Table 1: Number of companies producing a VAS included in full sample

\begin{tabular}{c|c}
\hline Year & Number of companies \\
\hline 1990 & 160 \\
\hline 1991 & 169 \\
\hline 1992 & 166 \\
\hline 1993 & 174 \\
\hline 1994 & 185 \\
\hline 1995 & 191 \\
\hline 1996 & 206 \\
\hline 1997 & 215 \\
\hline 1998 & 227 \\
\hline 1999 & 211 \\
\hline 2000 & 186 \\
\hline 2001 & 149 \\
\hline 2002 & 135 \\
\hline
\end{tabular}

It should be noted that the results form this study may not, based on size and function, accurately represent all industrial companies listed on the JSE Securities Exchange. However, in number, at least $50 \%$ of the industrial companies listed on the JSE Securities Exchange are included in the full sample, and as such the descriptive statistics will provide a useful indication of these companies’ added value.

It has previously been verified that companies in different industries do have different VA-ratios and the distribution of VA among the various stakeholders differ from industry to industry. The composition of the companies in the full sample differs from year to year industry-wise, as new companies started publishing value added statements and others stopped the publication thereof. The different industrial composition from year to year will most probably be one of the major reasons for any significant changes in the VA-ratios over time. It will therefore be necessary to control for industry in the sample and this can be done by using the same companies from year to year, thereby not changing the industrial composition of the sample over time.

A constant sample of companies that published a value added statement throughout the period 1990 to 2002 was used in order to do a statistical test over time. This sample consists of 36 companies. Companies that had major structural changes (for example a reverse takeover) are not included in any of the samples. However, companies with minor structural changes are not excluded from the samples and these minor changes, like subsidiaries being consolidated for the first time or acquisitions, may also affect the VA-ratios over time. 
As the sample of 36 companies (Appendix A) is quite small, another sample that exists of companies that were publishing value added statements from 1994 to 2002 was tested as well. This sample consists of 55 companies. Both these samples are used to determine whether there was a significant change over time in the VA-ratios. Since the aim was to compare more than two independent samples (the VA-ratios for every separate financial year), the nonparametric Kruskal-Wallis test was applied to the ratios in order to determine whether there were any significant differences between the years. A level of significance of five percent was utilised. The hypothesis used for this purpose was stated as follows:

$\mathrm{H}_{0}$ : The locations of all years are the same

$\mathrm{H}_{1}$ : The locations of at least two years differ.

\section{Results for full sample}

The following ratios were calculated per year as a percentage for each company included in every sample:

- Value added as a proportion of sales, defined as VA/sales;

- $\quad$ Salaries and wages as a proportion of value added, defined as salaries/VA;

- $\quad$ Dividends paid as a proportion of value added, defined as (preferred + ordinary dividends)/VA;

- Net interest paid as a proportion of value added, defined as (interest paid - interest received)/VA;

- Taxation as a proportion of value added, defined as taxation/VA;

- Minority interest as a proportion of value added, defined as minority interest/VA;

- $\quad$ Depreciation, defined as depreciation/VA; and
- $\quad$ Retained earnings as a proportion of value added, defined as retention/VA.

Since it cannot be assumed that distributions containing financial ratios are normally distributed, it was decided to test some of the VA-ratios for the full sample for normality. The Lilliefors test was employed at a level of significance of five percent in order to test VA/Sales and Salaries/VA for the following hypothesis:

$\mathrm{H}_{0}$ : The data follows a normal distribution

$\mathrm{H}_{1}$ : The data does not follow a normal distribution

The data was found to be overwhelmingly non-normally distributed (Table 2) therefore median values will be used henceforth in this paper. The VA/sales-ratio was found to be non-normally distributed in all but two of the thirteen years studied. The Kruskal-Wallis test was therefore applied in order to determine whether there was a significant difference in the central locations of the data between any of the years from 1990 to 2002. The test statistic resulted in 17,17 compared to the critical value of 21,03 . Since the test statistic is smaller than the critical value, there is not enough evidence to conclude that a difference in the central locations of the data exists among the thirteen years.

The absolute level of the median for the ratio VA/sales over all the sectors studied ranged from $27,34 \%$ in 2001 to $32,59 \%$ in 1992 with a value of $30,84 \%$ over the whole period (Table 3). This value is very similar to the levels previously observed in the United Kingdom in 1987 (30\%) and in South Africa from 1991 to 1997 (31,61\%) (Hamman \& Burger, 1999:268).

A common size value added statement was constructed for each year, using the median values of the distribution ratios of the companies during that year (Table 4). The median values for all the years were determined by calculating the median for all the generated ratios for every company in every year (2 374 observations).

Table 2: Lilliefors test for normality applied to VA-ratios 1990 to 2002 - full sample

\begin{tabular}{c|c|c|l|c|l}
\hline \multirow{2}{*}{ Year } & Critical value & \multicolumn{2}{|c|}{ VA/sales } & \multicolumn{2}{c}{ Salaries/VA } \\
\cline { 3 - 5 } & & Test statistic & \multicolumn{1}{c}{ Distribution } & Test statistic & Normal \\
\hline 1990 & 0,0700 & 0,0846 & Not normal & 0,0656 & Not normal \\
\hline 1991 & 0,0684 & 0,0711 & Not normal & 0,2399 & Not normal \\
\hline 1992 & 0,0688 & 0,0683 & Normal & 0,0533 & Normal \\
\hline 1993 & 0,0673 & 0,0765 & Not normal & 0,0976 & Not normal \\
\hline 1994 & 0,0651 & 0,0717 & Not normal & 0,0734 & Not normal \\
\hline 1995 & 0,0640 & 0,0528 & Normal & 0,1403 & Not normal \\
\hline 1996 & 0,0617 & 0,0808 & Not normal & 0,0553 & Normal \\
\hline 1997 & 0,0606 & 0,1197 & Not normal & 0,2504 & Not normal \\
\hline 1998 & 0,0589 & 0,1244 & Not normal & 0,2769 & Not normal \\
\hline 1999 & 0,0610 & 0,2106 & Not normal & 0,3536 & Not normal \\
\hline 2000 & 0,0650 & 0,1167 & Not normal & 0,3547 & Not normal \\
\hline 2001 & 0,0726 & 0,1355 & Not normal & 0,1969 & Not normal \\
\hline 2002 & 0,0763 & 0,1018 & Not normal & &
\end{tabular}


Table 3: Descriptive statistics of VA/sales from 1990 to 2002 - full sample

\begin{tabular}{c|c|c|c}
\hline Year & Number of observations & Mean & Median \\
\hline 1990 & 160 & $31,72 \%$ & $30,64 \%$ \\
\hline 1991 & 169 & $32,27 \%$ & $32,21 \%$ \\
\hline 1992 & 166 & $33,37 \%$ & $32,59 \%$ \\
\hline 1993 & 174 & $33,42 \%$ & $31,94 \%$ \\
\hline 1994 & 185 & $34,42 \%$ & $32,19 \%$ \\
\hline 1995 & 191 & $33,19 \%$ & $31,30 \%$ \\
\hline 1996 & 206 & $33,00 \%$ & $31,03 \%$ \\
\hline 1997 & 215 & $34,24 \%$ & $30,20 \%$ \\
\hline 1998 & 227 & $34,12 \%$ & $30,88 \%$ \\
\hline 1999 & 211 & $30,35 \%$ & $30,02 \%$ \\
\hline 2000 & 186 & $31,72 \%$ & $29,60 \%$ \\
\hline 2001 & 149 & $31,30 \%$ & $27,34 \%$ \\
\hline 2002 & 135 & $31,54 \%$ & $28,96 \%$ \\
\hline All & 2374 & $32,64 \%$ & $30,84 \%$ \\
\hline
\end{tabular}

Table 4: Median values of VA distribution ratios 1990 to 2002 - full sample

\begin{tabular}{|c|c|c|c|c|c|c|c|}
\hline Year & Dividends & Depreciation & Net Interest & Salaries & Taxation & Retention & $\begin{array}{r}\text { Minority } \\
\text { Interest }\end{array}$ \\
\hline 1990 & $6,24 \%$ & $6,69 \%$ & $5,23 \%$ & $59,06 \%$ & $9,81 \%$ & $8,30 \%$ & $0,26 \%$ \\
\hline 1991 & $5,71 \%$ & $6,84 \%$ & $5,40 \%$ & $60,78 \%$ & $8,57 \%$ & $7,66 \%$ & $0,07 \%$ \\
\hline 1992 & $5,13 \%$ & $7,39 \%$ & $3,66 \%$ & $63,53 \%$ & $7,86 \%$ & $7,27 \%$ & $0,05 \%$ \\
\hline 1993 & $4,98 \%$ & $8,02 \%$ & $3,56 \%$ & $65,44 \%$ & $6,60 \%$ & $7,55 \%$ & $0,10 \%$ \\
\hline 1994 & $4,55 \%$ & $7,93 \%$ & $3,06 \%$ & $64,44 \%$ & $6,51 \%$ & $9,12 \%$ & $0,08 \%$ \\
\hline 1995 & $4,89 \%$ & $7,37 \%$ & $2,86 \%$ & $63,18 \%$ & $6,89 \%$ & $10,60 \%$ & $0,07 \%$ \\
\hline 1996 & $4,73 \%$ & $7,58 \%$ & $2,99 \%$ & $60,97 \%$ & $7,00 \%$ & $11,49 \%$ & $0,03 \%$ \\
\hline 1997 & $5,23 \%$ & $7,69 \%$ & $1,86 \%$ & $60,47 \%$ & $6,54 \%$ & $12,59 \%$ & $0,03 \%$ \\
\hline 1998 & $5,02 \%$ & $7,55 \%$ & $1,04 \%$ & $60,22 \%$ & $7,36 \%$ & $13,64 \%$ & $0,05 \%$ \\
\hline 1999 & $3,17 \%$ & $8,01 \%$ & $1,14 \%$ & $58,75 \%$ & $5,93 \%$ & $14,14 \%$ & $0,00 \%$ \\
\hline 2000 & $1,77 \%$ & $8,53 \%$ & $2,42 \%$ & $62,00 \%$ & $5,65 \%$ & $12,13 \%$ & $0,00 \%$ \\
\hline 2001 & $2,37 \%$ & $10,04 \%$ & $2,58 \%$ & $63,95 \%$ & $5,72 \%$ & $12,37 \%$ & $0,07 \%$ \\
\hline 2002 & $3,07 \%$ & $9,79 \%$ & $3,96 \%$ & $59,89 \%$ & $7,00 \%$ & $12,66 \%$ & $0,00 \%$ \\
\hline All & $4,45 \%$ & $7,87 \%$ & $2,93 \%$ & $62,47 \%$ & $6,69 \%$ & $10,11 \%$ & $0,04 \%$ \\
\hline
\end{tabular}

Salaries and wages constitute the largest portion of the distribution of total value added over all the years studied (Table 4). The ratio salaries/VA was also found to be nonnormally distributed in most instances (Table 2). The Kruskal-Wallis test was again applied (Table 5) and it was determined that the central location of salaries and wages as a component of value added changed significantly between at least two of the years over the period studied. It was thus considered useful to determine whether any of the other distribution ratios showed a similar result (Table 5).

It is interesting to note that the ratio minority interest/VA was the only one for which there was not enough evidence to conclude that the central locations differed among the thirteen years. All the other ratios had significantly different central locations between at least two of the thirteen years in question. The two largest differences in central location occurred with the ratios retention/VA and dividends/VA, while salaries/VA varied the least.

Based on the full sample, the value added components fluctuated significantly over time. One possible explanation for the observed fluctuations may be that there was a change in the sector composition of listed companies over the period studied. It is therefore necessary that a constant sample that exists of the same companies over time be tested to see whether these fluctuations are a reflection of changes in broader economic conditions and regulatory changes or whether they are because of the composition of the sample.

\section{Results for constant samples}

For the constant sample from 1990 to 2002, the only ratio where there was enough evidence to conclude that the central locations of the data of at least two years differ significantly, was retention/VA (Table 6). Applying the Kruskal-Wallis test, it was determined that the earliest significant difference in the central locations of retention/VA was between 1994 and 1995. However, this sample only consists of 36 companies, and it may not be representative. It was therefore decided to expand the sample by excluding the years 1990 to 1993, where there was no significant difference among the central locations of retention/VA. The new constant sample from 1994 to 2002 consists of 55 companies. 
Table 5: Result of Kruskal-Wallis test performed on all VA distribution ratios - full sample

\begin{tabular}{l|c|c|c|c|c|c|c}
\hline & Dividends & Depreciation & Net Interest & Salaries & Taxation & Retention & $\begin{array}{c}\text { Minority } \\
\text { Interest }\end{array}$ \\
\hline Test statistic & $\mathbf{1 5 0 , 5 3}$ & $\mathbf{6 8 , 6 4}$ & $\mathbf{7 7 , 5 9}$ & $\mathbf{3 8 , 6 7}$ & $\mathbf{5 6 , 6 8}$ & $\mathbf{1 7 1 , 4 7}$ & 20,61 \\
\hline Critical value & 21,03 & 21,03 & 21,03 & 21,03 & 21,03 & 21,03 & 21,03 \\
\hline P-value & 0,000 & 0,000 & 0,000 & 0,000 & 0,000 & 0,000 & 0,006 \\
\hline
\end{tabular}

Although the constant sample from 1990 to 2002 indicated a significant difference in the central location of retention/VA, there was not enough evidence to conclude that the central location of this ratio differed significantly among the nine years in the constant sample from 1994 to 2002. Even though there specifically was a significant difference between 1994 and 1995 in the first constant sample, in the larger sample, the significance of the difference decreased. Ranked in order of significance (Table 10), retention/VA is now in the third place, according to the test statistic. In the constant sample from 1994 to 2002, it is only the ratio depreciation/VA where there is enough evidence to conclude that there was a significant difference in at least two of the central locations among the nine years.

The results of the constant samples therefore clearly indicate that the composition of the samples influence the VA-ratios. When the samples consists only of the same companies from year-to-year, the influence of sector differences is excluded and the results of the Kruskal-Wallis tests indicate that far less of the ratios differ significantly than when testing a full sample composed of different companies over time. This then explains the reason for the central locations differing in six of the ratios for the full sample. However, some of the ratios' central locations may differ significantly over time in the constant samples as can be seen from Table 6 .

\section{Explanations for differences in ratios over time}

Although the Kruskal-Wallis tests performed on the VA/Sales-ratio for all three samples, do not indicate that there is a significant difference between at least two of the years' central locations, there does seem to be a downward trend over time in VA/Sales (Table 7). In the full sample, year 1990 was below 31\%. Thereafter it increased to a high of 32,59\% in 1992. However, from 1997 onwards, it did not again reach $31 \%$. This trend is similar in the constant sample 1990 to 2002. Until 1996 the VA/Sales fluctuated from $32,09 \%$ in 1990 to a high of $34,74 \%$ in 1993 . However, from 1997 onwards, it fluctuated between 25,97\% and $31,54 \%$. The downward trend in the constant sample 1994 to 2002 only differed in that it only started in 1998.

Table 6: Results of Kruskal-Wallis test performed on all VA distribution ratios - constant samples

\begin{tabular}{l|c|c|c|r|c|c}
\hline \multirow{2}{*}{} & \multicolumn{3}{|c|}{$\begin{array}{c}\text { Constant sample } \\
\mathbf{1 9 9 0 - 2 0 0 2}(\mathbf{n = 3 6}\end{array}$} & \multicolumn{3}{c}{$\begin{array}{c}\text { Constant sample } \\
\text { 1994-2002 (n=55) }\end{array}$} \\
\cline { 2 - 7 } & Test statistic & Critical value & P-value & Test statistic & Critical value & P-value \\
\hline VA/Sales & 9,781 & 21,026 & 0,635 & 7,760 & 15,507 & 0,457 \\
\hline Dividends/VA & 11,910 & 21,026 & 0,453 & 6,430 & 15,507 & 0,599 \\
\hline Net Interest/VA & 11,949 & 21,026 & 0,450 & 2,860 & 15,507 & 0,943 \\
\hline Salaries/VA & 6,757 & 21,026 & 0,873 & 4,972 & 15,507 & 0,761 \\
\hline Taxation/VA & 16,543 & 21,026 & 0,168 & 14,395 & 15,507 & 0,072 \\
\hline Minority interest/VA & 4,541 & 21,026 & 0,972 & 1,634 & 15,507 & 0,990 \\
\hline Depreciation/VA & 16,470 & 21,026 & 0,171 & $\mathbf{1 9 , 5 0 2}$ & 15,507 & 0,012 \\
\hline Retention/VA & $\mathbf{2 9 , 9 7 8}$ & 21,026 & 0,003 & 12,645 & 15,507 & 0,125 \\
\hline
\end{tabular}

Table 7: Median of VA/Sales

\begin{tabular}{c|c|c|c}
\hline Year & $\begin{array}{c}\text { Full sample } \\
\mathbf{1 9 9 0 - 2 0 0 2}\end{array}$ & $\begin{array}{c}\text { Constant sample } \\
\mathbf{1 9 9 0 - 2 0 0 2}(\mathbf{n}=\mathbf{3 6})\end{array}$ & $\begin{array}{c}\text { Constant sample } \\
\mathbf{1 9 9 4 - 2 0 0 2}(\mathbf{n}=\mathbf{5 5})\end{array}$ \\
\hline 1990 & $30,64 \%$ & $32,09 \%$ & \\
\hline 1991 & $32,21 \%$ & $32,64 \%$ & \\
\hline 1992 & $32,59 \%$ & $34,08 \%$ & $33,00 \%$ \\
\hline 1993 & $31,94 \%$ & $34,74 \%$ & $33,13 \%$ \\
\hline 1994 & $32,19 \%$ & $34,18 \%$ & $32,38 \%$ \\
\hline 1995 & $31,30 \%$ & $32,86 \%$ & $32,73 \%$ \\
\hline 1996 & $31,03 \%$ & $32,86 \%$ & $31,88 \%$ \\
\hline 1997 & $30,20 \%$ & $30,54 \%$ & $29,73 \%$ \\
\hline 1998 & $30,88 \%$ & $31,54 \%$ & $29,66 \%$ \\
\hline 1999 & $30,02 \%$ & $29,26 \%$ & $27,42 \%$ \\
\hline 2000 & $29,60 \%$ & $29,14 \%$ & $28,85 \%$ \\
\hline
\end{tabular}


The distribution ratios of the two constant samples follow very much the same trends (Tables 8 and 9). This can be expected since the 36 companies of the constant sample from 1990 to 2002 form more than $65 \%$ of the companies included in the constant sample of 55 companies from 1994 to 2002. According to the Kruskal-Wallis test, only the central locations of the ratios retention/VA and minority interest/VA differ significantly between the two samples (Tables 8 and 9). The 36 companies of the constant sample 1990 to 2002 definitely have a larger minority interest in subsidiaries than the 19 companies that make up the constant sample 1994 to 2002. It is also interesting to note that the minority interest of both these samples decreased sharply 2001 onwards. It also seems as if the additional 19 companies do retain slightly more profit in the company, as the medians of this sample are higher than for the constant sample 1990 to 2002.

Three of the ratios are ranked among the first three in order of significance for both of the constant samples (Table 10), namely depreciation/VA, taxation/VA and retention/VA. There is a rational explanation for part of these differences over time.

Depreciation as a proportion of value added can be seen to increase from 1999 (Table 8 and 9). This increase may be because Statement AC 129 of 1999 of Generally Accepted Accounting Practice (SAICA, 1999) required that the intangible assets must be amortised for year-ends that start on or after 1 January 2000, and the amortisation is included in depreciation from that date. Some companies may have applied this statement from an earlier date. The KruskalWallis test indicates that there is not enough evidence to conclude that there is a significant difference in the central locations among the years 1994 to 1999. With 2000 included, there is however, enough evidence that there is a significant difference in the central locations between at least two of the seven years. This underlines the above reasoning that amortisation may have caused the shift in this ratio.

Retention and dividends may be the last allocations made after other obligations such as taxes, interest and salaries and wages have already been met, and depreciation been provided for. This means that retention and dividends will probably fluctuate more between years than other components depending on the relative yearly prosperity of the companies studied, and the prevailing economic conditions. As the retention component of value added may be influenced by broader economic conditions, the relationship between retention as a proportion of value added and GDP growth on a yearly basis is depicted in Figure 1. From the graph, is does seem as if the ratio retention/VA follows the GDP growth generally, but it is acknowledged that many more factors do influence retention.

Table 8: Median values of distribution ratios - constant sample 1990 to 2002

\begin{tabular}{c|c|c|c|c|c|c|c}
\hline Year & Dividends & Depreciation & Net Interest & Salaries & Taxation & Retention & $\begin{array}{c}\text { Minority } \\
\text { Interest }\end{array}$ \\
\hline 1990 & $6,50 \%$ & $8,11 \%$ & $4,41 \%$ & $57,18 \%$ & $10,39 \%$ & $7,17 \%$ & $0,51 \%$ \\
\hline 1991 & $6,01 \%$ & $7,93 \%$ & $4,33 \%$ & $60,72 \%$ & $9,96 \%$ & $7,85 \%$ & $0,42 \%$ \\
\hline 1992 & $5,31 \%$ & $8,75 \%$ & $3,31 \%$ & $63,17 \%$ & $9,02 \%$ & $7,95 \%$ & $0,53 \%$ \\
\hline 1993 & $5,13 \%$ & $9,49 \%$ & $3,27 \%$ & $64,74 \%$ & $7,61 \%$ & $7,71 \%$ & $0,47 \%$ \\
\hline 1994 & $5,52 \%$ & $8,17 \%$ & $3,22 \%$ & $65,18 \%$ & $7,24 \%$ & $8,30 \%$ & $0,57 \%$ \\
\hline 1995 & $6,10 \%$ & $8,17 \%$ & $1,83 \%$ & $62,05 \%$ & $8,98 \%$ & $10,97 \%$ & $0,53 \%$ \\
\hline 1996 & $6,03 \%$ & $8,51 \%$ & $2,19 \%$ & $58,22 \%$ & $7,83 \%$ & $10,29 \%$ & $0,47 \%$ \\
\hline 1997 & $6,29 \%$ & $8,39 \%$ & $1,13 \%$ & $60,39 \%$ & $8,90 \%$ & $10,97 \%$ & $0,66 \%$ \\
\hline 1998 & $6,55 \%$ & $9,65 \%$ & $0,09 \%$ & $60,23 \%$ & $8,22 \%$ & $11,08 \%$ & $0,49 \%$ \\
\hline 1999 & $6,00 \%$ & $10,50 \%$ & $3,28 \%$ & $61,91 \%$ & $5,75 \%$ & $6,90 \%$ & $0,38 \%$ \\
\hline 2000 & $5,27 \%$ & $10,55 \%$ & $2,05 \%$ & $59,65 \%$ & $7,03 \%$ & $9,45 \%$ & $0,51 \%$ \\
\hline 2001 & $4,25 \%$ & $10,54 \%$ & $2,92 \%$ & $61,97 \%$ & $6,63 \%$ & $10,40 \%$ & $0,19 \%$ \\
\hline 2002 & $4,70 \%$ & $9,03 \%$ & $3,08 \%$ & $59,86 \%$ & $7,83 \%$ & $12,91 \%$ & $0,19 \%$ \\
\hline All & $5,73 \%$ & $8,95 \%$ & $2,52 \%$ & $60,73 \%$ & $7,93 \%$ & $9,17 \%$ & $0,49 \%$ \\
\hline
\end{tabular}

Table 9: Median values of distribution ratios - constant sample 1994 to 2002

\begin{tabular}{c|c|c|c|c|r|r|r}
\hline Year & Dividends & Depreciation & Net Interest & Salaries & Taxation & Retention & $\begin{array}{c}\text { Minority } \\
\text { Interest }\end{array}$ \\
\hline 1994 & $5,55 \%$ & $7,50 \%$ & $3,19 \%$ & $63,87 \%$ & $7,56 \%$ & $9,31 \%$ & $0,03 \%$ \\
\hline 1995 & $5,61 \%$ & $7,84 \%$ & $2,37 \%$ & $61,58 \%$ & $8,89 \%$ & $11,52 \%$ & $0,09 \%$ \\
\hline 1996 & $5,63 \%$ & $8,02 \%$ & $2,51 \%$ & $59,26 \%$ & $7,93 \%$ & $11,23 \%$ & $0,14 \%$ \\
\hline 1997 & $6,04 \%$ & $8,31 \%$ & $1,85 \%$ & $60,54 \%$ & $8,37 \%$ & $11,62 \%$ & $0,17 \%$ \\
\hline 1998 & $6,76 \%$ & $8,61 \%$ & $1,13 \%$ & $60,65 \%$ & $7,54 \%$ & $11,32 \%$ & $0,20 \%$ \\
\hline 1999 & $6,10 \%$ & $10,25 \%$ & $3,11 \%$ & $60,83 \%$ & $6,00 \%$ & $7,73 \%$ & $0,20 \%$ \\
\hline 2000 & $5,76 \%$ & $10,67 \%$ & $1,92 \%$ & $59,85 \%$ & $7,01 \%$ & $11,81 \%$ & $0,24 \%$ \\
\hline 2001 & $5,12 \%$ & $10,96 \%$ & $2,09 \%$ & $63,20 \%$ & $6,71 \%$ & $10,76 \%$ & $0,09 \%$ \\
\hline 2002 & $5,04 \%$ & $9,14 \%$ & $2,36 \%$ & $59,42 \%$ & $8,39 \%$ & $14,43 \%$ & $0,11 \%$ \\
\hline All & $5,69 \%$ & $8,91 \%$ & $2,36 \%$ & $60,65 \%$ & $7,61 \%$ & $11,13 \%$ & $0,15 \%$ \\
\hline
\end{tabular}


Table 10: Distribution ratios ranked in order from most significant to non-significant according to test statistic of Kruskal-Wallis test

\begin{tabular}{|c|c|c|c|}
\hline & Full sample & $\begin{array}{l}\text { Constant sample } \\
1990-2002(n=36)\end{array}$ & $\begin{array}{l}\text { Constant sample } \\
1994-2002(n=55)\end{array}$ \\
\hline Depreciation/VA & 4 & 3 & 1 \\
\hline Taxation/VA & 5 & 2 & 2 \\
\hline Retention/VA & 1 & 1 & 3 \\
\hline Dividends/VA & 2 & 5 & 4 \\
\hline Salaries/VA & 6 & 6 & 5 \\
\hline Net Interest/VA & 3 & 4 & 6 \\
\hline Minority interest/VA & 7 & 7 & 7 \\
\hline
\end{tabular}

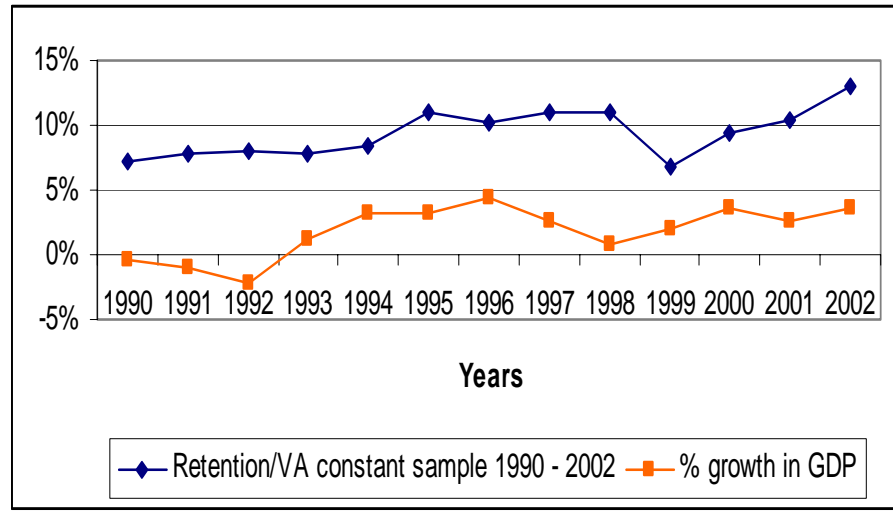

Figure 1: Retention/VA and \% GDP growth per year from 1990 to 2002

The decrease in dividends observed in 2000 and in 2001 (8 and 9) may partly be explained by a change in the accounting treatment of dividends. Statement AC 130 of Generally Accepted Accounting Practice (SAICA, 1999), which came into effect for year-ends starting on or after 1 January 2000, required that all dividends be reported only once a current obligation to pay them exists. Prior to this, dividends could be taken into account even if only declared after the end of a financial year, with no current obligation at year-end. The change in GAAP may thus have resulted in companies showing less dividends in one of their yearly financial statements, in either the year 2000 or 2001, depending on their financial year-end.

Normal taxation will be influenced by the prosperity of the company, as it is based on the taxable income, as well as on the tax rates as determined by law. The fluctuation in the taxation component of value added may be attributed in some part to a step-wise decrease in the company normal tax rate from an effective rate of 50\% until 31 March 1991 to a rate of 30\% effective from 1 April 1999. The introduction of secondary tax on companies (STC) from 17 March 1993 will also influence this allocation. In Figure 2 the ratio, taxation/VA and the trend in the weighed tax rates as regulated by law is depicted. The weighing was done considering the date of the change in tax rates as well as the proportion of value added broadly subject to normal taxation and broadly subject to STC. From Figure 2 it can be seen that the weighed rate decreased over time, as did the allocation of value added to taxation.
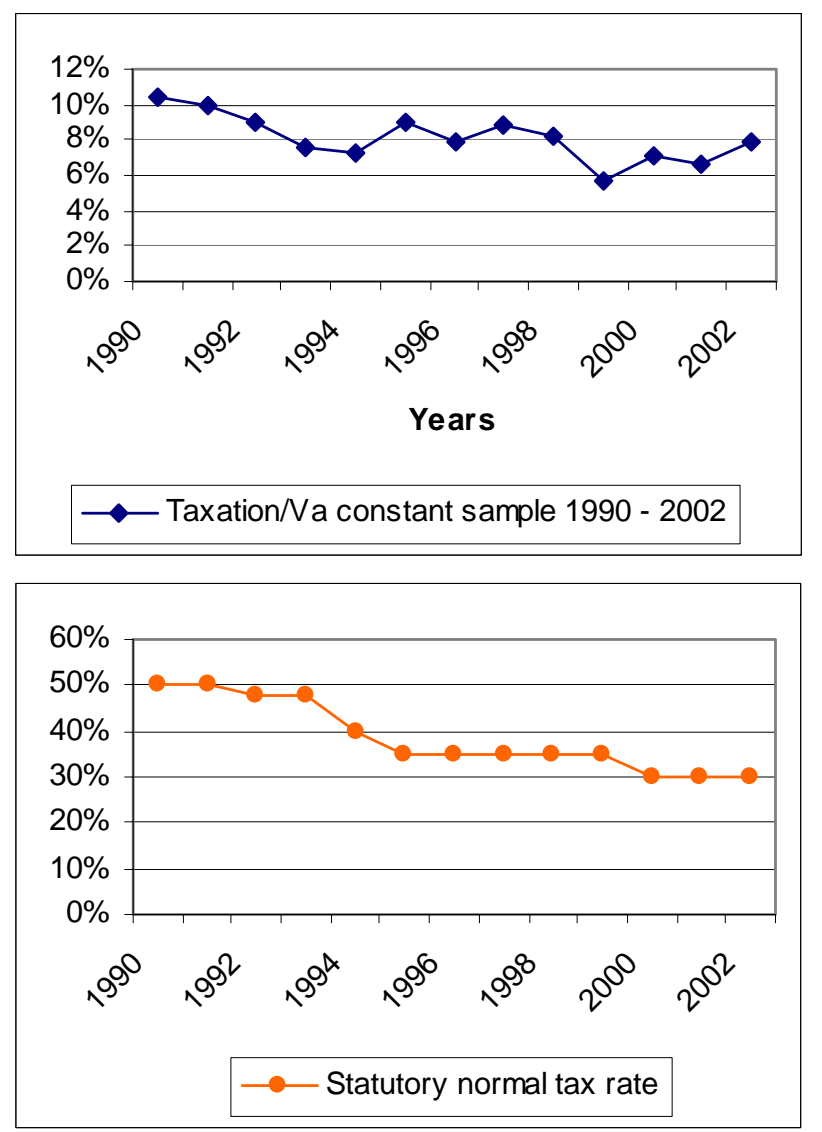

Figure 2: Trends in tax rates and the ratio taxation/VA

\section{Conclusion}

The purpose of this study was to expand on the existing knowledge available concerning the trends and characteristics of ratios calculated from value added statement data in South Africa. The ratio VA/sales and the VA distribution ratios were calculated for three samples:

- A full sample from 1990 to 2002, consisting of all the listed South African companies preparing a value added statement;

- A constant sample of 36 companies that existed from 1990 to 2002; and

- A constant sample of 55 companies that existed from 1994 to 2002. 
Although the Kruskal-Wallis test led to the conclusion that there is not enough evidence that the central locations of the ratio $\mathrm{VA}$ /sales of at least two years differ significantly, a slight downward trend from 1997/1998 was found. The range of this ratio is similar to the levels reported by previous studies in South Africa and the United Kingdom.

Applying the Kruskal-Wallis test, it was determined that six of the VA distribution ratios had differences in the central location in at least two of the years among all the years that were significant. However, when performing the same test on the constant samples, there was only one distribution ratio in each sample with a significant difference in the central locations among the years. These ratios were retention/VA for the constant sample from 1990 to 2002 and depreciation/VA for the constant sample from 1994 to 2002. The only other ratio where the test statistic was near to the critical value, although not significant, was taxation/VA.

These three ratios are the only distribution ratios where a possible shift did occur over time in the allocation of value added. The change in depreciation could very well have been caused by a change in the accounting treatment of amortisation of intangible assets, while the change in taxation was probably caused by the changes in the normal tax rate as well as the introduction of STC. Retention is a balancing figure - the leftovers after the other allocations have been done - it can therefore be expected that this ratio will be influenced by the changes in all the other allocations. The general prosperity of the company and the economy will also influence retention, as the total value added will change accordingly and that will determine what is being left for retention in the company. As the growth in the GDP increased during the period under review, it was no surprise to find an increase in the ratio retention/VA.

\section{References}

Accounting Standards Steering Committee. 1975. The corporate report. London: The Committee.

Bryant, J. 1989. 'Assessing organisation strength using added value', Long Range Planning, 22(3): 34-44.

Cox, B. 1979. Value added: An appreciation for the accountant concerned with industry. London: Heinemann.

Evraert, S. 1998. 'Usefulness of value added reporting: A review and synthesis of the literature', Managerial Finance, 24(11): 1-15.

Haller, A. \& Stolowy, H. 1995. 'Value added in financial accounting: A comparative study between Germany and France', [online] URL: http://campus hec fr/profs/stolowy/perso/articles/Va.pdf . Accessed 20 May 2004.

Hamman, W.D. \& Burger, J. 1999. 'RSA value-added statements: Certain ratios 1991-1997'. In Terblanch, N. (Ed.). Proceedings of the $11^{\text {th }}$ Annual Conference of the Southern African Institute for Management Scientists. Stellenbosch: SAIMS.

Jordaan, A.C., Smit, E.v.d.M. \& Hamman, W.D. 1994. 'An investigation into the normality of the distributions of financial ratios of listed South African industrial companies', South African Journal of Business Management, 25(2): 65-71.

Laubscher, E. \& Shuttleworth, B. 2004. Why disclose information voluntarily? Accountancy SA, May: 8-10.

Morley, M.F. 1979. 'The value added statement in Britain', The Accounting Review, 54(3): 618-629.

Riahi-Belkaoui, A. 1992. Value added reporting: Lessons for the United States. New York: Quorum Books.

Rutherford, B.A. 1981. 'Five fallacies about value added', Management Accountant, September: 31-33.

Schuitema, J. 2001. 'Value added statement: The case for its wider use and sensible standard', Accountancy SA, October: 8-9.

SAICA (South African Institute of Chartered Accountants). 1999. Intangible assets. AC129. Revised edition. Johannesburg: SAICA Kengray.

SAICA (South African Institute of Chartered Accountants). 1999. Provisions, contingent liabilities and contingent assets. AC130. Revised edition. Johannesburg: SAICA Kengray.

South African Reserve Bank. 2002. Annual Economic Report. Pretoria: SARB.

Steyn, W. \& Hamman, W. 2002. 'A conceptual model for the interpretation and evaluation of VAS', Accountancy SA, July: 16-19.

United Kingdom. 2004. The Value Added Scoreboard 2004. London: Department of Trade and Industry, Business Finance \& Investment Unit.

Van Staden, C. 2003. 'The relevance of theories of political economy to the understanding of financial reporting in South Africa: the case of value added statements', Accounting Forum, 27(2): 224-245. 
APPENDIX A

COMPANIES INCLUDED IN CONSTANT SAMPLE OF 36 FROM 1990-2002

\begin{tabular}{l|l}
\hline AECI & Metair \\
\hline African Oxygen & Metro Cash and Carry \\
\hline Allied Electronics Corporation & Murray \& Roberts Holdings \\
\hline Allied Technologies & Nampak \\
\hline Amalgamated Beverage Industries & Oceana Group \\
\hline Cashbuild & Pepkor \\
\hline Chemical Services & Pick 'n Pay Stores \\
\hline Combined Motor Holdings & Pretoria Portland Cement Company \\
\hline Crookes Brothers & Putco \\
\hline Edgars Consolidated Stores & Reunert \\
\hline Glodina Holdings & SASOL \\
\hline Grindrod & Seardel Investment Corporation \\
\hline Imperial Holdings & Shoprite \\
\hline Iscor & Sun International (SA) \\
\hline Jasco Electronics Holdings & Tiger Brands \\
\hline Kersaf Investments & Tongaat-Hullet Group \\
\hline
\end{tabular}

\section{IN ADDITION TO THE ABOVE, THE FOLLOWING COMPANIES WERE INCLUDED IN THE CONSTANT SAMPLE OF 55 FROM 1994-2002}

\begin{tabular}{l|l}
\hline Barloworld & Hunt Leuchars Hepburn \\
\hline Bearing Man & Illovo \\
\hline Bidvest & JD Group \\
\hline Ceramics & Masonite \\
\hline City Lodge & MNet \\
\hline Concor & Mr Price \\
\hline Ellerines & Nictus \\
\hline Foschini & Ozz \\
\hline Highveld & Tiger Wheels \\
\hline Hudaco & \\
\hline
\end{tabular}

